\title{
Examining Mathematics Teachers' Views on 4MAT Teaching Model $^{1}$
}

\author{
Zeynep Bahar Erşen \\ Afyon Kocatepe University. Turkey \\ Bülent Güven \\ Black Sea Technical University. Turkey
}

\begin{abstract}
4MAT teaching model has undoubtedly been mentioned and studied mostly in recent years. The aim of this study was to present the views on 4MAT teaching model of the elementary mathematic teachers applying the model. The case study was carried out with three elementary mathematics teachers having different occupational experience. Semi-structured interviews were used as data collection tools. Views of the teachers about 4MAT model application process were positive; teachers made different suggestions in order to apply model more efficiently and have the required success from these practices.
\end{abstract}

Key words: 4MAT, teaching model, teachers' views

\section{INTRODUCTION}

The education program in our country is based on constructivism, and is the result of research carried out in the field of mathematics education and a review of the programs adopted by developed countries; it is underpinned by the principle that "every child can learn mathematics." Having said that, one of the principles that are coming to the fore in the new primary education programs is activism, while the other is student-centeredness (Acat and Ekinci, 2005). These principles also individualize learning in the individual by prioritizing effective participation in the education process. For this reason, teaching models sensitive to individual differences have gained importance in the new curriculum. The most radical change is undoubtedly the fact that teachers and students no longer play the roles of talker and listener respectively since under this new program the students construct their own knowledge, skills and interpretations, participating actively in the learning process. In short, it is the notion of a student-centered, non-rote system that lies at the heart of the new primary education program's philosophy.

It is clear that in accordance with the new education program's philosophy and stated aims, knowledge is not independent of the individual, and that it is structured by the individual. In this context, there is of course no question of information being imparted to the student by direct instruction with the student only listening. For this reason, in addition to the changes in the skills that the students are going to acquire under the new education program, there is one more area, perhaps the most important one, where change is taking place: that of the role of the teacher. Indeed, the more accurately a teaching program is understood and implemented by teachers, the more successful the students will be at that level; the degree of success in

1 This article has been produced from her master thesis titled "Reflections of Practice of 4MAT Education Model By Elementary School Mathematic Teachers" 
education will also increase at that rate. This begs the question: what kind of teacher does the new education program want?

Mathematics education in previous years took the path: definition, formula, example, practice, familiarization. The new program suggests the following path: problem, discovery, make no assumptions, verify, associate, generalize. This cycle sees the teacher transformed from "instructor" to "moderator," "guide" and "facilitator (Baki, 2008). The main role of the teacher in the new education program is to regulate the learning-teaching environment during the course and guide the students during this process. In addition to this, like Brooks and Brooks (1999) stated, the teacher - who puts the constructivist approach into practice - needs to possess the skills to use the physical materials interactively while showing how to access information, to change instructional strategy depending on the situation, to check what previous knowledge the students may have about the concept they are going to learn, to be able to encourage students to communicate with him/herself as well as with each other in order to make the students active, to be able to change students' perspectives on things, to be able to open various hypotheses to debate to drawing on students' experiences, and to ensure that the students construct relationships and create metaphors.

In addition to the rolls imposed on the teacher by the new education program, there are bound to be changed, too, to the methods and techniques employed by the teacher in class. Apart from the guidelines that bring to mind the teacher-centered approach in the new program, since the point being stressed is that it is student-centered, there is a need for teachers who are skilled at making the student's carry out meaningful learning, and who understand and can apply modern learning concepts (Baki, 2008). It is for this reason that together with the new mathematics program, teachers have also been introduced to modern teaching models, methods and strategies. The teachers, too, have benefited a great deal from this and have begun to create many different learning environments in their classes. One model of instruction, the use of which in classrooms by teachers has been highlighted as important, and which has become the subject of an increasing number of studies, is the 4MAT model.

Built on the differences in the way people learn, the 4MAT system has been developed to assist teachers in organizing the teaching process. The 4MAT system is a learning cycle consisting of eight stages making use of operating preferences based on individual learning preferences and brain dominance. Introduced in order to increase teacher awareness as to why some topics can be learned by some students at the desired rate while some cannot, the 4MAT model is underpinned by research in the fields of education, operation, psychology and neurology (Hazır-Bıkmaz, 2002).

Together with the new education program, which accepts individualized learning as its basic vision, it states in Article 2 of National Education Law Number 1739, which stipulates the main goals of Turkish National Education, that the aim is for individuals to be taught in accordance with their interest, aptitude and ability (Saban, 2002). For this reason, the learner has to take responsibility for learning from start to finish, and to participate actively in the learning process. The acceptance of individual learning has drawn attention to individual differences; the concept of learning style has emerged (Boydak, 2005). This concept was first introduced in 1960 by Rita Dunn, who described her learning style as every student using different and unique pathways while preparing to learn now and difficult information, learning it and recalling it (Dunn and Stevenson, 1997). And so, learning styles, which differ from person to person, formed the start point for 4MAT, and this model was used to explain what kind of a learning environment could be designed for individuals who learn differently. 
The 4MAT teaching model has two important features that set it above other models. The first of this is that 4MAT has been built on learning theories that are generally well respected among educators, while the second is that despite being few in number, independent and longterm comparative studies carried out in a controlled fashion have been applied using the 4MAT model (Appell, 2002). In studies abroad in which practices based on the 4MAT model were compared to textbooks, it was seen that those practices in which the 4MAT model was used increased success and permanence to a large degree (Wilkerson, 1986; Bowers, 1987; Appell, 1991; Ursin, 1995; Driskill,1998; Jackson, 1999; Jackson, 2001; Delaney; 2002). Students have generally been the focus of studies looking at the 4MAT model in our country (Dikkartın, 2006; ; Elçi, 2008; Ergin, 2011; Mutlu, 2004; Öztürk, 2007; Tatar, 2006; Uysal, 2009). The results obtained in those studies have shown that the 4MAT teaching model has a positive effect on student's learning, achievements and retention. It is important in terms of being able to see the consequences of its application and contribution to teaching that this instructional model, which emerged as a result of academic studies carried out both at home and abroad, is implemented by our teachers and their opinions sought. The basic goal of this study, which in this respect differs from other studies in the literature, is to determine what those math teachers who used the 4MAT model think of it.

\section{The 4MAT Teaching Model}

The 4MAT learning system, which was developed in the 1970s by Bernice McCarthy, is a model that demonstrates the relationship between learning styles and the brain's left/right hemispheres, and the importance of the questions "why, what, how and if this then what," which individuals who possess every style of learning seek the answers to when learning (Ekici, 2003). This model is based on the theory of learning expounded by Kolb following research that looked at the brain's hemispheres. McCarthy in turn made some alterations to Kolb's theory, and prepared a teaching model for primary and middle education (Ojure, 1997).

The 4MAT system that McCarthy introduced consists of four quarters, which she created by taking into account an individual's learning styles. A teaching system was designed consisting of eight stages taking into consideration the functions of the brain's left and right hemispheres in every individual. When designing this model, McCarthy was considerably influenced by research into learning styles as well as research into brain hemispheres. She believed that even though different lobes work together, the fact that they possessed separate fields of ability and that the differences when a neutral system was used revealed personal differences, were two topics of immediate interest to the world of education (McCarthy, 2000)

After six years of experimental work, McCarthy had classified the learning styles into four categories, which she called: Type 1 learners (innovative), Type 2 learners (analytic), Type 3 learners (common sense) and Type 4 learners (dynamic) (McCarthy, 1982, 1985, 1987, 1990, 1997, 2000; Morris ve McCarthy, 1990). According to McCarthy (1987), each one of these four learning styles is a quarter, and when instruction is given that matches the individual in one of those quarters, that person will succeed. The 4MAT teaching model's planning process is carried out taking into consideration the characteristics of individuals possessing these learning styles (McCarthy, 1987; McCarthy, 2003).

\section{Type One Learners (Imaginative Learners)}

Imaginative learners perceive information in concrete terms then reflect on it, and are located in the first quarter. These individuals give priority to feelings, they are human centered, good observers of people and good listeners. They are thinkers with powerful imaginations and who believe their own experiences. They take responsibility and work well together. Since they look at events from a broad perspective they can sometimes have trouble making decisions. They 
think that schools are detached from the personal endeavors they find interesting. They have difficulty in relating what they learn at school and what they need to understand their development and their life. Individuals who have this type of learning style need to know "why" they are learning. In addition, these individuals need to be given examples from the their own life experiences when learning. People with this style of learning love to communicate with people, and since they value other people's ideas it would be useful to use such techniques as brainstorming, case studies, and team work (McCarthy, 1990; McCarthy, 2000; McCarthy and McCarthy, 2006).

Type 1 learners' strengths lie in the fact that they are innovative and imaginative thinkers. Their preferred professions are: consultancy, teaching, organizational development, the humanities and social sciences. Their favorite question is, "Why?" (McCarthy, 2003).

\section{Type 2 Learners (Analytic Learners)}

Analytic learners perceive information abstractly and process it through reflection, and are located in the second quarter. Learning by contemplating, these individuals feel the need to know what experts think. They enjoy the traditional classroom environment and find ideas impressive. Individuals with this type of learning style prefer to organize concepts, follow details one step at a time, and reach objective conclusions by making observations and mentally organizing these observations. They see schools as the ideal environment for their needs. While giving information to such students, they need to be given the answer to the question, "What am I learning?" Since they prefer to work independently, the most appropriate techniques for analytic learners will be to ask questions that can be worked out by instruction, problem solving, individual effort and mental organization (McCarthy, 1990; McCarthy, 2000; McCarhty and McCarthy, 2006).

Type 2 learners' strengths lie in their ability to create concepts and models. Their preferred professions are: Mathematics, research and planning departments, the natural sciences. Their favorite question is, "What?" (McCarthy, 1987).

\section{Type 3 Learners (Commonsense Learners)}

Type 4 learners perceive information abstractly, process it actively, and are located in the third quarter. They combine theory with practice. They will use something if they believe it will help. They prefer to be able to see what the things they learn are good for, to be able to test what they have learned, and to learn by making experiments where they can actively use their manual skills. Since they want to work on life problems they consider time spent in school as being wasted. They value strategic thinking. Work aimed at classroom practice, and activities that can help students adopt different perspectives in their approach will be useful. For these types of students, worksheets can be used that help them develop " problem solving techniques (McCarthy, 1987; McCarthy, 1990; McCarthy, 2000).

The strengths of Type 3 learners lie in their being able to put ideas into practice. Their favorite question is, "How is it done?" Their preferred professions are: physician, applied sciences and engineering (McCarthy, 1987).

\section{Type 4 Learners (Dynamic Learners)}

Dynamic learners perceive information concretely and process it actively, and are located in the fourth quarter. They learn by trial and error, and are thrilled by new things. They are people who like change and who adapt easily. They are individuals who can easily form relationships with people, who take risks and who learn by self-discovery. They like openended questions, questioning, acting on intuition, and persuading other people. For this type of 
student, school is boring and overly organized. Since dynamic learners value other people's ideas it will be useful to use such techniques as brainstorming, working in small groups, and case studies (McCarthy, 1987; McCarthy, 1990; McCarthy and McCarthy, 2000).

Type 4 learners strengths lie in their ability to carry out plans and to fight. Their favorite question is, "If, then what?" Their preferred professions are: marketing, entertainment, the educational and social professions (McCarthy, 2003).

\section{METHOD}

In this study, it was decided that the best way to determine what teachers thought of 4MAT was the special case study. This is because this model gives the researcher the opportunity to dwell on a special situation or incident in depth, and to present different elements in the study (Patton, 2005).

\section{Study Group}

The sample group for the study consists of three primary school mathematics teachers with different professional experiences working at three different primary schools in central Trabzon. Since it was thought that getting the opinions of teachers with different professional experiences would provide a broader perspective, purposeful sampling was used. As required by research ethics, the actual names of the classroom teachers participating in the study are not used; instead the codes T1, T2 and T3 are used to represent the teachers.

When the offer to take part in the study was presented to teacher T1, this teacher of 23 years professional experience did not turn it down. Having spent the past five years at the same school, this teacher has undertaking administrative duties at this school, and also at other primary and high school equivalent schools. The teacher's current schools is one of the oldest schools in Trabzon Province, and is well known for its achievements in teaching. Even though the school building is not very large, a considerably large number of students learn there due to intense parental demand. In addition, the school has all the necessary teaching materials. The teacher's lesson schedule was packed due to having to teach second stage primary education classes as well, so the teacher informed the researcher when the most appropriate lesson times would be. The class that was decided on for observation was Classroom 6-C, which accommodates 38 people. Even though the classroom was of average size, the large student body had a negative effect on the classroom atmosphere. Furthermore, the teacher was seen to have trouble managing the class from time to time due to the students being particularly active. When the teacher was asked how the lesson was usually taught, teacher T3 said they made use of textbooks and exercise books. The observation process began after the model was explained, but the teacher was unable to show the researcher any interest in applying the method. Due to a number of health reasons, teacher T3 was unable to attend some lessons, and this led to the implementation process being extended. Listened to for eight class hours, teacher T3 explained "Fraction Division and Fraction Problems" for three class hours, "Decimals" for two class hours, "Proportion-Ratio" for two class hours, and "Length Measurements" for one class hour.

When it was stated that we wanted to work with teacher T2, who has 10 years of professional experience, the teacher hesitated to be included in the sample group, but this hesitation disappeared after the necessary training for the model was given. At their current school for four years now, the teacher previously worked at a primary school in a village. The school building where teacher T2 works is large and the classes have the ideal dimensions for lessons to be given. According to the central examine results, the achievement levels of the students that come to this school, which was seen to have all the necessary materials, are in parallel 
with the average achievement scores for the province. In addition to the 25-seat Classroom 6$\mathrm{A}$, the teacher also teaches other second stage primary education classes, and stated that he attends in-service training courses so as to better himself, and that he applies what he learns there in his classes. Teacher T2 was very enthusiastic throughout the study period, and did his best to prepare lessons in every topic in accordance with the 4MAT model. During this process, which observed nine classroom hours, the teacher re-arranged the students' seating so as to manage the classroom better and so that the practice should be productive, showing the importance that the teacher attached to the study. During the observation period, the teacher explained "Division in Fractions and Fraction Problems" for three hours, "Decimals and Comparative Decimals, Ranking" for two hours, "Resolving Decimals" for two hours, and "Addition and Subtraction in Decimals" for two hours.

Teacher T3 has two years of professional experience and began his working life at a district primary school. Teacher $\mathrm{T} 1$ has started his post-graduate education, and the school where he works in central Trabzon possesses all the necessary teaching tools and devices. The school building is large with a large number of classrooms, each classroom sitting a maximum of 25 students. The observed Class 7-D is a successful, special class created by the school's administration according to the students' average grades. The teacher stated that since it was a special class he had no problems with teaching it. Teaching the sixth and eighth grades, teacher T1 said that since he had recently graduated and was continuing with his post-graduate education, he was making maximum use of the innovations introduced by the new teaching program, and was teaching his classes according to the constructivist approach. The teacher gladly accepted the offer to work with him, and his enthusiasm during the implementation process stood out. During this process, teacher T1 frequently chatted with the researcher about the 4MAT learning model, and was seen to take the study seriously. Listened to for five classroom hours, teacher T3 explained "Linear Equations and Charts" for three hours, and the "Cartesian Coordinates System for two hours.

\section{Design of the study}

After the researcher had scanned the literature, it was decided to focus on what teachers who have used the 4MAT learning model think of it. To begin with, a pilot study was made. The model was explained over four hours to a mathematics teacher who volunteered to apply the model. Afterwards, the teacher was observed over two weeks as he tried to teach his lessons using the 4MAT model. During this process, it was observed that the teacher had misunderstood the model in some places, and so eight hours of 4MAT training was given to the teachers in the actual study. Table 1 shows what was done during this training process. After observing the three teachers who had volunteered to apply the learning model, interviews were held to determine what they thought about the 4MAT learning model.

Table 1. Done during the 4MAT training process

Done during the education process Duration

Giving general information about the 4MAT learning model One hour

Talking about the characteristics of individuals possessing 4MAT learning styles One hour

Explaining each quarter of the 4MAT learning cycle Two

hours

Discussion of lesson plans prepared according to the 4MAT learning model Three

hours

Discussion of experiences gained from pilot study, and answering questions put One hour by the teachers doing the actual study 


\section{Data Collection Tools}

During this study, semi-structured interviews were used to reveal what the teachers thought of the 4MAT learning model and their experiences. For this method, the researcher prepares the interview questions before the interview begins, but may be flexible depending on the individual and the conditions. The researcher can reorganize earlier prepared questions, or allow a broad discussion of the questions. In short, during a semi-structured interview there is plenty of opportunities to change the order of the questions and to explain the questions in more detail (Çepni, 2009).

In order to reveal what the teachers thought about the 4MAT learning model, they were asked this question during the interview: "After the training you have received for the 4MAT learning model and the sessions you have carried out, what do you think of this model?" Also, "In your opinion, what are the 4MAT method's advantages and disadvantages?" Those were the questions asked. Afterwards, the following questions were asked to determine the teachers' thought on the preparation process that took place prior to implementing 4MAT: "Which of 4MAT's quarters was easiest to plan for? Why?" And, "Which of 4MAT's quarters were harder to plan for? Why?" Those were the questions that were asked. "Are you considering using the 4MAT learning model in your lessons from now on after this study? Why?" Using those questions, an attempt was made to reveal the attitudes developed by the teachers with respect to the method's practicability. During the interviews, the researcher put different questions to the teachers depending on the answers they gave. All the interviews made with the teachers were recorded using a digital audio recording device with each teacher's permission. Afterward, the study detailed how these recorded data were put into a computer, turned into text, analyzed, and how the conclusions were reached. In addition to this, while a descriptive approach was adopted in displaying the study's data, a choice was made to use direct quotes in order to increase the study's reliability.

\section{Data Analysis}

Content analysis was carried out in order to determine what the teachers thought of 4MAT. The expressions used by the teachers were examined, then categories and themes were identified according to the codes that were created. Furthermore, liberal use was made of direct teachers' quotes in order to support the data in the table.

\section{FINDINGS}

\section{Teachers' General Opinions of the 4MAT Learning Model}

"After the training you have received for the 4MAT learning model and the sessions you have carried out, what do you think of this model?" The answers given by the teachers to this question are presented in Table 2. 
Table 2. Teachers' general opinions of 4MAT

\begin{tabular}{|c|c|c|c|}
\hline Theme & Categories & Codes & Participants \\
\hline \multirow{16}{*}{ 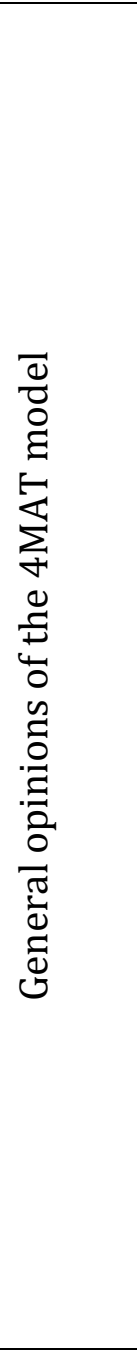 } & \multirow{13}{*}{$\begin{array}{l}\text { Positive } \\
\text { views } \\
\text { about the } \\
\text { model }\end{array}$} & $\begin{array}{l}\text { The students are able to get a good idea beforehand } \\
\text { by giving examples from their daily lives. }\end{array}$ & $\mathrm{T} 1$ \\
\hline & & $\begin{array}{l}\text { Using such methods as discussion and brainstorming } \\
\text { allows the students to generate ideas. }\end{array}$ & T1, T3 \\
\hline & & It awakens the students' desire to learn. & T3 \\
\hline & & It enables students to define concepts. & T3 \\
\hline & & It uses a lot of methods and materials. & $\mathrm{T} 1, \mathrm{~T} 2, \mathrm{~T} 3$ \\
\hline & & $\begin{array}{l}\text { Concepts become concrete through the activities that } \\
\text { are made and the materials that are used. }\end{array}$ & $\mathrm{T} 1, \mathrm{~T} 2, \mathrm{~T} 3$ \\
\hline & & Students can see how formulas work in practice. & T1, T3 \\
\hline & & $\begin{array}{l}\text { It enables students to participate actively in the } \\
\text { lesson. }\end{array}$ & $\mathrm{T} 2$ \\
\hline & & $\begin{array}{l}\text { Giving examples from real-life problems helps } \\
\text { increase the students' belief in the usefulness of } \\
\text { mathematics. }\end{array}$ & $\mathrm{T} 1$ \\
\hline & & Activities make the lessons more enjoyable. & $\mathrm{T} 2$ \\
\hline & & It makes it easier for students to grasp the topic. & $\mathrm{T} 1, \mathrm{~T} 2, \mathrm{~T} 3$ \\
\hline & & $\begin{array}{l}\text { It makes the students socialize by sharing their ideas } \\
\text { with one another. }\end{array}$ & $\mathrm{T} 2$ \\
\hline & & $\begin{array}{l}\text { It creates an environment that works for students of } \\
\text { all the different learning types. }\end{array}$ & $\mathrm{T} 2$ \\
\hline & \multirow{3}{*}{$\begin{array}{l}\text { Negative views } \\
\text { about the } \\
\text { model }\end{array}$} & $\begin{array}{l}\text { Crowded classrooms make it hard to apply the } \\
\text { model. }\end{array}$ & $\mathrm{T} 1, \mathrm{~T} 2$ \\
\hline & & It creates problems with respect to timing. & T3 \\
\hline & & $\begin{array}{l}\text { Since the students already know the topic from cram } \\
\text { school they can get bored in the first half of the } \\
\text { model. }\end{array}$ & T3 \\
\hline
\end{tabular}

As can be seen from the table, the teachers said that a lot of material is used with the 4MAT model, that these materials help make concepts concrete and thus make it easier to grasp topics. In addition to this, teacher T1 said that taking examples and problems from daily life helped give students an idea what to expect, helped them see how formulas worked in practice, and was influential in their belief in the usefulness of mathematics.

Teacher T1: "Introducing the topic by giving examples from daily life gives the students preliminary knowledge about the topic and warms them up. Once the concepts have been given, the students can see how formulas work using the examples given by their teacher... When the teacher leaves the students alone with the daily life problems that they are going to apply the concepts and formulas they have learned, the students can see that what they learn in class is going to help in their daily lives and work." These comments reveal their opinions of the model. Teacher T3 stated that the activities done in the first quarter awakened the students' desire to learn, that 4MAT helped students define concepts, and that methods such as discussion and brainstorming, which are frequently used in this model, help the students come up with ideas.

Teacher T3 expressed his ideas saying: "Having an answer to the question as to why they are learning something helps the students learn with meaning, and focuses their interest on the topic. In this way, the desire to learn the topic is born... In the second quarter, in which the teacher is more active and sets the correct learning environment by demonstrating his skill, the students are 
able to define concepts thanks to activities. Methods used in 4MAT's quarters like discussion and brainstorming are very effective in helping the students gain different perspectives, and generating ideas".

Teacher T2 said that this model made students more active in class by creating an appropriate learning environment for every student, and that with 4MAT the lessons were mode enjoyable. The teacher also said that since the learning process included the exchange of ideas it was a model that helped students socialize.

Teacher T3: "Learning is an active process and it is a known fact that learning is more effective and lasting in highly stimulating environments. I observed that in those lessons where we used the 4MAT method the students participated more actively. Giving the students more say and allowing them to share their ideas helped them socialize in the classroom... The use of concrete materials made the mathematics lesson more enjoyable and made the topic they were going to learn easier to understand."

In addition to these positive views about 4MAT, teachers $\mathrm{T} 1$ and $\mathrm{T} 2$ expressed their opinion that applying this model in crowded classrooms could be problematic.

Teacher T1 said: "...It was just that with my class being so crowded at the time, the resulting noise and chaos prevented the model from being applied properly. I think that applying this model in classes with fewer students will make for more successful results.

Teacher T2: "It was a case of partially completed activities failing to achieve the goal. It is not always possible to guide students' attention in crowded classrooms. It can be said that the negative situations experienced inside the class atmosphere prevent some students from fully grasping the topic. When applied to a group of 30 students, this method might not yield the same results as seen in a group of 10 students. Therefore, it may not always be possible to follow the steps flawlessly in a crowded classroom or obtain the desired results.

Teacher T3 also stated that applying the model could lose time during the lesson; also that the students appeared bored during the first stages of 4MAT since they had already learned about the topic in cram schools.

Teacher T3: "... Yet, no matter how useful I believe those quarters to be, our student body demands a lot of care. For example, since my students thought they had already learned the topic I was about to teach in cram school, they got bored during the first stages. Furthermore, since the curriculum is packed, I think that applying this model is going to create problems time-wise.

The teachers stated that with the 4MAT model the desire to learn formed in the students, that grasping the topic was easier, that the model helped the students come up with new ideas, and that it made the students more active and social; yet for all that, there could still be problems implementing the model in crowded classrooms. Indeed, during the observation process it was seen that teacher T1 experienced difficulty in maintaining a hold on his crowded class from time to time. Another situation voiced by teacher T3 was that students who also go to cram schools got bored when the model was being applied. Going by this, it can be said that the cram school mentality in our country is having an adverse effect on the process of implementing the 4MAT model, which is better suited to the constructivist approach.

\section{Teachers Opinions of 4MAT Lesson Planning}

The teachers were asked: "Which quarter of the 4MAT process was easiest to plan? Why?" Their answers are presented in Table 3. 
Table 3. The quarters where the teachers found it easy to make lesson plans

\begin{tabular}{ccl}
\hline \multirow{2}{*}{ Participants } & \multicolumn{2}{c}{ CATEGORIES } \\
\cline { 2 - 3 } & $\begin{array}{c}\text { The 4MAT Quarter } \\
\text { That is Easier to Plan }\end{array}$ & \multicolumn{1}{c}{ Reasoning } \\
\hline T1 & First Quarter & It is easier to begin by taking from the students' lives. \\
\hline T2 & Second Quarter & $\begin{array}{l}\text { Being similar to the traditional approach planning is } \\
\text { easier. }\end{array}$ \\
\hline T3 & First Quarter & It is easier to come up with activities related to daily life. \\
\hline
\end{tabular}

Teachers T1 and T3 said that when planning in accordance with 4MAT planning for the 1st quarter was comparatively easier than for the other quarters. They attributed this to it being easier to find examples and activities from daily life.

Teacher T1: "The first quarter. This is because it is easier for you and them to give examples at this stage if you start with individuals' lives. Almost the entire class participates actively in the lesson during this stage. But this is not true for all topics. For examples, while students are easily able to give examples of measuring from their daily lives, they will find it hard to give examples of multiplication and division.

Although teacher T1 said that he found first quarter planning to be easier, he also stated that the preparation process could change when the topic changed. It can be seen that teacher T3 gave similar answers to teacher T1.

Teacher T3:"Planning for the first quarter is easier. This is because I personally find it easier to explain the reasons for what they are about to learn and to come up with activities relating to daily life. This changes from topic to topic, though. For example, I had problems in the first quarter when the topic was equations."

Teacher T2 said that it was easier to make plans for the second quarter. He attributed this to the quarter resembling the traditional method.

Teacher T2: "It was easier to plan for the second quarter. I think that the more successful the first stage is, and the more the student can be pulled into the topic and feel ready, the easier it is going to be to plan the next stages. Naturally, all the steps have to be in accord with each other. You make a good intro and use carefully selected questions in the first part, but if that is followed by a poorly prepared exercise paper, it is going to overshadow all the activities. I can say that if a good experience was generated in the first stage, I found it easier to prepare exercise sheets, plan for a slide show, or similar activities in the second stage. Since this quarter resembles the traditional approach where the teacher is active, it is easier to plan and implement. What is difficult here is, like I said before, preparing activities that will engage the students in the lesson in topics dominated by abstract concepts."

Table 18 presents information on which quarters were more challenging to the teachers when planning in accordance with the 4MAT model: 
Table 4. The quarters the teachers found hard to make lesson plans

\begin{tabular}{|c|c|c|}
\hline \multirow{2}{*}{\multicolumn{2}{|c|}{$\begin{array}{l}\text { The 4MAT quarter } \\
\text { Participants that was harder to plan }\end{array}$}} & CATEGORIES \\
\hline & & Reasoning \\
\hline T1 & Fourth Quarter & $\begin{array}{l}\text { It is hard to find problems or activities that will enable } \\
\text { the students to come up with new things relating to the } \\
\text { taught concepts. }\end{array}$ \\
\hline T2 & First Quarter & $\begin{array}{l}\text { It is not easy to find activities that are going to elicit } \\
\text { concrete experiences }\end{array}$ \\
\hline T3 & Third Quarter & $\begin{array}{l}\text { I found it hard to design practical activities that were } \\
\text { going to attract the attention of my students, who just } \\
\text { wanted to solve the test. }\end{array}$ \\
\hline
\end{tabular}

Teacher T1 stated that while planning what to do in a 4MAT lesson he found it hard finding problems or activities for 4MAT's final quarter. In observations made during the lesson, too, it was seen that teacher T1 had not planned problems or activities that would enable the students to think creatively or form new experiences.

Teacher T1:"Our primary school students have trouble creating new things. In this respect, it is hard to find questions and activities for the fourth quarter. Since the number of students that are going to be active in the fourth quarter is not to exceed $10 \%$ of the class, this situation can create problems. Yet, what is expected with this model is to make a large proportion of the class take part in the lesson.

Teacher T2 stated that he had trouble finding activities that would attract the students' attention during the first quarter of the lesson. He said the reason for this was that it was hard to make some topics in mathematics concrete.

Teacher T2:"Planning for the first quarter was harder. This step is more a step for imaginative learner students, and it was quite hard to present a concrete equivalent of a mathematical topic to the class, and to plan an activity relating to it. In order to create a topic-related experience, I came up with some activities after thinking long and hard how to create an experience between the children's world and mathematical reality. It is not easy to prepare an activity that can answer the question "why?" when learning the topic even if it is section where all the students are having fun. It is not easy to find concrete examples that can positively affect every student's desire to learn what is being taught, if the information being taught is going to meet the student's needs."

Teacher T3, for his part, said that he had problems creating practice activities fitting the third step because the students wanted to solve the test in class.

Teacher T3: "Planning for the third quarter was a little harder. My students did not really want to learn the topic; they just wanted to solve the test. Unfortunately, it is important that they solve the tests quickly at the end of term exam, and for them studying for the exam is more important than the concept.

Considering this comment, it can be said that one of the factors preventing 4MAT from being implemented is our own country's exam system. The responsibility that comes with being a special class makes the students focus only on the end of year exam, and prevents a rich learning environment from being formed. 


\section{Teachers Opinions as to the Advantages/Disadvantages of 4MAT}

Table 5 summarizes the teachers' opinions relating to aspects of the model they considered advantageous or disadvantageous, as expressed during the interviews.

Table 5. Teachers' opinions of the 4MAT model's advantages and disadvantages

\begin{tabular}{|c|c|c|}
\hline Theme & Codes & \\
\hline \multirow{6}{*}{ 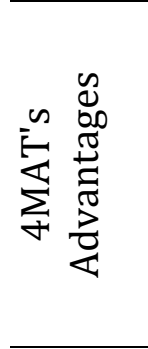 } & It allows the teacher and the students to brainstorm. & $\mathrm{T} 1$ \\
\hline & It makes topics easier to conceptualize. & T1 \\
\hline & It motivates the students for the lesson. & T2 \\
\hline & It helps with permanent learning. & T2, T3 \\
\hline & $\begin{array}{l}\text { It enables the students to form a good infrastructure for the } \\
\text { other topics they are going to learn. }\end{array}$ & $\mathrm{T} 2$ \\
\hline & It saves the teacher from having to explain a topic over and over. & \\
\hline \multirow{3}{*}{ 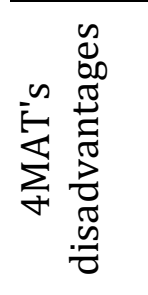 } & $\begin{array}{l}\text { Since very few of the students possess the ability to come up with new } \\
\text { information/concepts } \\
\text { the desired class participation for the last quarter is not achieved. }\end{array}$ & T1 \\
\hline & It takes time. & $\mathrm{T} 1, \mathrm{~T} 2, \mathrm{~T} 3$ \\
\hline & $\begin{array}{l}\text { It imposes an extra burden on the teacher during the } \\
\text { planning stage (such as activities, preparing materials etc.). }\end{array}$ & $\mathrm{T} 2$ \\
\hline
\end{tabular}

Teacher T1 stated that 4MAT drives the teacher to come up with new ideas concerning the design of new activities during the lesson planning process, and makes the student think during every stage of the lesson. He said that this production process increased the teacher's and the students' ability to think in many directions.

Teacher T1:"During this process, while the teacher is planning the lesson for each quarter he has to find examples and problems to attract the students' attention, create activities that enable the students to formulate the concept, show the students where they can use what they have learned in real life, and ensure that they create new things. This being the case, it is not just the student who has to think from many angles, the teacher who is going to ensure this also has to be able to brainstorm at least as much as the student. This model ensures this."

Teacher T2 stated that the model motivates the students well, and that by addressing every student it saves him from having to repeat the topic over and over again, and added that since it provided an effective learning environment, a good infrastructure was prepared for every topic to be learned. In addition, teacher T3 thought like teacher T2 that this model helps with permanent learning.

Teacher T2:"Teachers can have trouble motivating the students when introducing the lesson. In a lesson planned using the 4MAT method, the students can be motivated by providing them with examples of concrete experiences. It gives every student an equal opportunity to learn information, and by incorporating many different activities it ensures permanent learning. Even though it is hard for teachers to plan in the first stage, for the students it gives them the opportunity to create infrastructure for the topics that are going to learn later, and saves the teacher from the bother of having to repeat the topic over and over again for each and every student."

Teacher T3: "If we are talking about advantages, I believe the model ensures permanent learning." 
While talking about the advantageous situations provided by the 4MAT model, the teachers also mentioned those situations they saw as disadvantageous in 4MAT in the light of their experience. For example, teacher T1 stated that there was not enough student participation in the activities in the learning environment that was to be created in the final quarter. He said the reason for this was the small number of students in the final quarter with a powerful ability to think creatively and come up with new things.

Teacher T1:"...However, some of the activities that are effective in the model may not be suitable for our classes. This is because if we were to conduct a study, I am sure that only a very number of students will be able to create different solutions to a question they have never encountered before. I mean, they don't think creatively. Therefore, while the goal in 4MAT is to make the students active, particularly in the fourth quarter, that kind of environment did not form in my class."

The three primary school mathematics teachers also said by way of disadvantage that 4MAT creates problems with respect to timing in the application process.

Teacher T1: "I think that this method might cause us to overrun the time in which we are supposed to explain a topic."

Teacher T2: "...Using this model, which is based as much as possible on practice and activities, the lesson time exceeds the duration set aside for the topic in the curriculum."

Teacher T3: "...It's just that it takes too much time to explain a topic in keeping with 4MAT. I think this is a disadvantage."

While teacher T3 thought that 4MAT's only disadvantage is that it creates a time problem, teacher T2 said that not only thins but the model also important extra burden on the teacher during the lesson preparation stage.

Teacher T2: "...Furthermore, there is an additional burden on the teacher when making a plan. There can be difficulties obtaining and preparing the materials that the students need to use."

\section{Teachers' View on Using 4MAT Later on}

The teachers were asked: "Are you considering using the 4MAT learning model in your lessons from now on after this study? Why?" The answers given by the teachers to this question are summarized in Table 6. 
Table 6. Teachers' views as to using 4MAT in later lessons

\begin{tabular}{|c|c|c|c|}
\hline \multirow[t]{2}{*}{ Participants } & \multicolumn{3}{|c|}{ CATEGORIES } \\
\hline & $\begin{array}{l}\text { Preferenc } \\
\text { Situation }\end{array}$ & Reason for Preference & $\begin{array}{c}\text { Suggestions Given for } \\
\text { More Successful Model Applications }\end{array}$ \\
\hline $\mathrm{T} 1$ & $\begin{array}{l}\text { Yes, from } \\
\text { time } \\
\text { to time. }\end{array}$ & $\begin{array}{l}\text { It would be better } \\
\text { for use with topics that } \\
\text { can be associated with } \\
\text { daily life. }\end{array}$ & $\begin{array}{l}\text { The classroom's physical environment and } \\
\text { class body must be ideal, the prepared } \\
\text { teaching material must be topic appropriate. }\end{array}$ \\
\hline $\mathrm{T} 2$ & Yes. & $\begin{array}{l}\text { The activities make } \\
\text { the lesson more } \\
\text { enjoyable, more } \\
\text { productive. }\end{array}$ & $\begin{array}{l}\text { The class body must be few in number. } \\
\text { Information/material banks need to be } \\
\text { created. } \\
\text { The necessary infrastructure needs to be } \\
\text { formed at education faculties for teacher } \\
\text { candidates. } \\
\text { In-service training courses should be } \\
\text { provided for teachers. }\end{array}$ \\
\hline T3 & Yes. & $\begin{array}{l}\text { It awakens } \\
\text { the desire to learn } \\
\text { in students, and } \\
\text { includes the } \\
\text { students in every } \\
\text { stage of the lesson. }\end{array}$ & $\begin{array}{l}\text { The learning environment must be } \\
\text { furnished with technological tools and } \\
\text { equipment. } \\
\text { Exams need to be abolished. } \\
\text { The students should be convinced that what } \\
\text { they learn in school shapes their lives. }\end{array}$ \\
\hline
\end{tabular}

All three teachers said they were thinking about using this model in their lessons from now on. While teacher T1 said that this method could be used for lessons that were easier to make concrete, teacher T3 stated that this model awoke the desire to learn in students, and teacher T2 said they wanted to use this model because it made the lessons more enjoyable and more productive.

Teacher T1: "I am thinking about using it occasionally. I think it would be best used in topics relating to real life situations."

Teacher T2:"Yes. This is because the lessons are more enjoyable and more productive."

Teacher T3: "Actually, I am thinking of using this model. This is because with this model the student's curiosity is aroused, and participation in the lesson is sincere."

While the teachers are considering using 4MAT in their lessons, they did make suggestions as to how the model could be applied more successfully. Teacher T1 stated that the classrooms' physical conditions needed to be altered and that the material prepared and presented by the teachers needed to be topic-appropriate, and that there was a need for products that would draw the students into the lesson.

Teacher T1 said: "...Furthermore, it would be better to use this method in situations where the environment, the class body and the materials are more fitting. If not, it will not be possible to achieve the desired success when it is used."

Teacher T3 stated there was a need to furnish all classrooms with technological tools and equipment. In talks between lessons the teachers said that in computer-assisted mathematics applications, even going to the laboratory ruined the students' motivation. He believes that the 
materials to be used should be present in the class environment. In addition to this, the teacher favors abolishing the SBS exam system in our country. Like in the answers he gave to our other questions, teacher T3 was seen to be annoyed by the fact that his students were focused on exams. This is why while teacher T3 was advocating the abolition of central exams so that this model could succeed, he also stated that the students needed to be made aware that the school was an institution that prepares them for life.

Teacher T3: "...In order for the method to succeed the learning environment should be modernized (if, for example, a projector and a computer were to be in every classroom), the SBS exam should be abolished, and the students should be made to believe wholeheartedly that what they are learning is preparing them for life, and is really very important for their lives. I think that if schools can be turned into real homes for education and learning, this and similar methods will serve a purpose."

Stating that the class body needed to be small, teacher T2 said that material/activities banks needed to be formed that could be used in 4MAT applications with the goal of helping the teacher in the lesson planning stage. He also stressed that sufficient training needed to be given to teachers on in-service courses, and before that, to teacher candidates at faculties. Talking with teacher $\mathrm{T} 2$, the teacher made similar suggestions with respect to teacher training.

Teacher T2: "...Crowded classrooms are a factor that prevents better results from being achieved. Therefore, the number of students in the classrooms should be reduced. I think that every teacher is going to want to use this method but that an information bank needs to be formed for drama, tales and similar activities relating to the topics in the curriculum. Similarly, the necessary infrastructure needs to be given to teachers in mathematics lessons in education faculties, and if necessary practical lessons should be given to mathematics teachers via in-service training courses.

When the answers that were given to the questions are examined overall, it can be seen that the teachers think positively about this model. It is clear from the opinions given by our teachers that every model comes with both advantages and disadvantages. However, taking individual differences and the brain's hemispherical working system as its base, the 4MAT learning model is one that our teachers are thinking of using later on thanks to the enriched learning environment that it offers. In our country, where the constructivist is still trying to fit in, the suggestions put forward by the teachers in the name of obtaining even better results from the model's application are important for the studies that are to be done in the name of education from now on.

\section{DISCUSSION AND CONCLUSIONS}

With respect to 4MAT, in which many teaching methods and techniques offered by the constructivist approach are used, the teachers believed that the desired level of productivity could not be achieved in crowded classrooms, that the model created timing problems, and that it was hard to prepare material prior to the lesson. In other studies carried out in our country looking at how to apply the new approach in our country (Güneş, 2008; Gökçek; 2008; Ergen, 2009; Kalender, 2006) the teachers were seen to complain about similar problems. Teacher T1 stated that one important factor in the model's success was the students' preparedness, meaning the knowledge they already had. Indeed, Ozdemir et al. (2002) found results supporting the idea that the most important factor influencing learning was the individual's existing knowledge. 
Teacher T3 said that the exam reality in our country had an adverse effect on the model's practicability. Furthermore, in the interviews it was seen that the teacher was worried about his students' success in the central exams and that the students wanted exercises that focused on the exams. In the work by Gökçek (2008) and Kızılaslan Tunçer (2011), the teachers were observed to say that they were worried about the central exams and that the central exams did not match the new program. Again, from what was said in the interview, it is understood that the administration wants an exam-focused working environment since teacher T3 is conducting a class consisting of successful students. Yet, the teachers need an administration that is willing here so that they can fully implement the new strategies in lessons during the teaching-learning process (Railsback, 2002). It is clear from this that when it comes to implementing 4MAT or similar models there is a need not just for teachers but also for administrations with innovative qualities.

In addition to voicing their troubles with respect to the use of 4MAT, the teachers also believe that it is an effective model that is enjoyable, that makes the students active and more social, that increases interest in the lesson, that enables conceptual learning, that takes individual differences into consideration, and that enables creative thinking. Not only do they think this, they also stated that they are thinking about applying this method in future lessons. In this regard, the studies demonstrate parallels with the findings in Ojure's (1997) study that after teachers were given 4MAT training they had positive thoughts about teaching the 4MAT model.

\section{References}

Acat, B. \& Ekinci, A. (2005). Yapılandırmacı felsefe ve yeni müfredat programina etkileri. XIV. Ulusal Eğitim Bilimleri Kongresi Bildiriler Kitabı (s. 22-10). Denizli: Pamukkale Üniversitesi Eğitim Fakültesi.

Appell, C. J. (1991). The effect of instructional material and learning style preference on test performance of undergraduate nursind students (Unpublished Ph. D. Thessis). The University of Nebraska - Lincoln.

Baki, A. (2008). Kuramdan uygulamaya matematik eğitimi (4. Baskı). Trabzon: Harf Eğitim Yayıncılık.

Bowers, P.S. 1987. The Effects of the 4MAT System on Achievement and Attitudes in Science (Unpublished PhD thesis). The University of North Carolina at Cahapel Hill.

Boydak, H. A. (2005). Öğrenme stilleri (5. Baskı). İstanbul: Beyaz Yayınları.

Brooks, J. \& Brooks, M. (1999). The case for constructivist classrooms. USA:ASCD.

Çepni, S. (2009). Araştırma ve proje çalışmalarına giriş (4. Baskı). Trabzon: Celepler Yayıncılık.

Delaney, A. (2002). Better teaching model? Middle school science classroom using the 4MAT instructional strategy vs. lessons created without this model (Unpublished masters' thesis). University of North Texas, USA.

Dikkartın, F. T. (2006). Geometri öğretiminde 4MAT öğretim modelinin öğrenci başarısı ve tutumları üzerine etkisi (Yüksek Lisans Tezi). Balıkesir Üniversitesi Fen Bilimler Enstitüsü, İlköğretim Matematik Eğitimi Anabilim Dalı, Balıkesir.

Driskill, W. C. (1998). Effectiveness of the 4MAT instructional design on personal and cognitive attitudes of students (Unpublished Ph. D. Thesis). The University of Texas at Austin, USA.

Dunn, R. \& Stevenson, J. M. (1997). Teaching diverse college students to study with a learning styles prescription. College Student Journal, 31, 333-339.

Ekici, G. (2003). Öğrenme stiline dayali öğretim ve biyoloji dersi öğretimine yönelik ders plani örnekleri. Ankara: Gazi Kitabevi.

Elçi, A. N. (2008. Öğrenme stillerine uygun olarak seçilen öğrenme yöntemlerinin öğrencinin başarısına, matematiğe yönelik tutumuna ve kaygısına etkileri (Doktora Tezi). Dokuz Eylül Üniversitesi, İzmir.

Ergen, S. (2009). İlköğretim eğitim sisteminde kalabalık sınıfların yönetimi ve Esenyurt İlköğretim okullarında bir araştırma (Yüksek Lisans Tezi). Beykent Üniversitesi, Sosyal Bilimler Enstitüsü, İstanbul.

Ergin, S. (2011). Fizik eğitiminde 4MAT öğretim yönteminin farkli öğrenme stillerine sahip lise öğrencilerinin iş, güç ve enerji konusundaki başarisina etkisi (Doktora Tezi). Gazi Üniversitesi, Ankara. 
Gökçek, T. (2008). Altıncı sınıf matematik öğretmenlerinin yeni ilköğretim programına uyum sürecinin incelenmesi (Doktora Tezi). Karadeniz Teknik Üniversitesi, Fen Bilimleri Enstitüsü, İlköğretim Anabilim Dalı, Trabzon.

Güneș, G. (2008). Yeni ilköğretim matematik dersi öğretim programının öğretme öğrenme ortamına yansımaları (Doktora Tezi). Karadeniz Teknik Üniversitesi, Fen Bilimleri Enstitüsü, İlköğretim Anabilim Dalı, Trabzon.

Hazır-Bıkmaz, F. (2002). Öğrenme biçimlerini okula getirmede 4MAT sistemini kullanma. (Çeviri, Bernice Mc Carty). Ankara Üniversitesi Ĕ̆itim Bilimleri Fakültesi Dergisi, 34(12), 105-111.

Jackson, H. B. (1999). Teaching to a Diversity of Learning Styles: Using 4MAT Model in a Block Scheduled School (Unpublished Ph. Thesis). The University of Pittsburgh.

Jackson, P. R. (2001). The effects of teaching methods and 4MAT learning styles on community college students' achievements, attitudes and retention in introductory microbiology (Unpublished Ph. D. Thesis). Lynn University, USA.

Kalender, A. (2006). Sınıf öğretmenlerinin yapılandırmacı yaklaşım temelli "Yeni Matematik Programı” nın uygulanması sürecinde karşılaştığı sorunlar ve bu sorunların çözümüne yönelik önerileri (Yüksek Lisans Tezi). Dokuz Eylül Üniversitesi, Eğitim Bilimleri Enstitüsü, İzmir.

Kızılaslan-Tunçer, B. (2011). İlköğretim öğretmenlerinin 2005 İlköğretim programında yer alan etkinlikler, proje ödevleri ve seviye belirleme sınavına ilişkin görüşlerinin değerlendirilmesi. e-Journal of New World Sciences Academy Education Sciences, 6(1), 801-809.

McCarthy, B. (1982). Improving Staff Development Through CBAM and 4MAT. Educational Leadership, 40(1), 2025.

McCarthy, B. (1985). What 4MAT Training Teaches us About Staff Development. Educational Leadership, 42(7), 61-68.

McCarthy, B. (1987). The 4MAT system: Teaching to learning styles with right/left mode techniques. Barrington: Excel Inc.

McCarthy, B. (1990). Using the 4MAT System to Bring Learning Styles to Schools. Educational Leadership, $48(2), 31-37$.

McCarthy, B. (1997). A Tale of Four Learners: 4MAT Learning Styles. Educational Leadership, 54(6), 46-51.

McCarthy, B. (2000). About teaching 4MAT in the classroom. Illionois: About Learning Inc.

McCarthy, B. (2003). About Teaching Companion 4MAT Implementation Workbook. Wauconda, IL: About Learning.

McCarthy, B. \& McCarthy, D. (2006). Teaching around the 4MAT cycle: Desinging instruction for diverse learning styles. California: Corwin Pres.

Morris, S. \& McCarthy, B. (1999). 4MAT in Action (4th Edition), About Learning. Inc. http://www.aboutlearning.com/files/4MAT-in-Action.pdf 14.11.2010.

Mutlu, M. (2004). İlköğretim 8.Sınıffen bilgisi dersinde fotosentez- hücresel solunum konusunun 4MAT öğretim modeli kullanılarak öğretilmesinin öğrenci tutum ve başarısı üzerine etkisi (Yayımlanmamış Doktora Tezi). Gazi Üniversitesi Eğitim Bilimleri Enstitüsü, Ankara.

Ojure, L. P. (1997). An Investigation of the Relationship Between Teachers' Participation in 4MAT Fundamentals Training and Teachers' Perception of Teacher Efficacy. Dissertation submitted to the Faculty of the Virginia Polytechnic Institute and State University in partial fulfillment of the requirements for the degree of Doctor of Philosophy in Curriculum and Instruction.

Özdemir, Ö., Ülker, M., Uyguç, M., Huyugüzel, P., Çavaş, B. \& Kesercioğlu, T. (2002). Fen eğitiminde inşacı yaklaşım ve kavram haritalarını kullanımının öğrenci başarılarına olan etkileri. V. Ulusal Fen Bilimleri ve Matematik Ĕgitimi Kongresi, ODTÜ, Ankara.

Öztürk, Z. (2007). Öğrenme stilleri ve 4MAT modeline dayalı öğretimin lise tarih derslerindeki öğrenci başarısına etkisi (Yüksek Lisans Tezi). Gazi Üniversitesi Eğitim Bilimleri Enstitüsü Tarih Eğitimi Anabilim Dalı, Ankara.

Patton, M.Q. (2005). Qualitative Research: Encyclopedia of Statistics in Behavioral Science. New Jersey: John Wiley \& Sons.

Railsback, J. (2002). “Project-based instruction: Creating excitement for learning.” Portland, OR: Northwest Regional Educational Laboratory. http://www.nwrel.org/request/ 2002aug/index.html.

Saban, A. (2002). Çoklu zeka teorisi ve eğitim. Ankara: Nobel Yayın Dağıtım. 
Erşen, Z. B., \& Güven, B. (2018). Examining Mathematics Teachers' Views on 4MAT Teaching Model ${ }^{1}$. Advances in Social Sciences Research Journal, 5(6) 487-504.

Tatar, E. (2006). İkili işlem kavramı ile ilgili öğrenme güçlüklerinin belirlenmesi ve 4MAT yönteminin başarıya etkisi (Doktora Tezi). Atatürk Üniversitesi, Fen Bilimleri Enstitüsü, Erzurum.

Ursin, V. D. (1995). Effects of the 4MAT System of Instruction on Achievement, Products and Attitudes Towards Science of Ninth Grade Students (Unpublished Ph.D. Thesis).The University of Connecticut.

Uysal, F. (2009). İlköğretim 6.Sınıf Matematik Dersi “Kesirler” Konusunun Öğretiminde 4MAT Öğrenme Stili Modelinin Öğrenci Başarısına Etkisi (Yüksek Lisans Tezi). Gazi Üniversitesi, Eğitim Bilimleri Enstitüsü, Ankara.

Wilkerson, R.M. 1986. An Evaluation of The Effects of The 4MAT System of Instruction on Academic Achievement and Retention of Learning Hemisphericity (Unpublished Ph.D. Thessis). The University of North Carolina at Chapel Hill. 